\title{
Developing environmental principles, criteria, indicators and norms for potato production in South Africa through field surveys and modelling
}

\author{
A.C. Franke $^{\text {a,* }}$, J.M. Steyn ${ }^{\text {b }}$, K.S. Ranger ${ }^{\text {c,d }}$, A.J. Haverkort ${ }^{\mathrm{a}, \mathrm{b}}$ \\ a Agrosystems Research, Plant Sciences Group, Wageningen University and Research Centre, Droevendaalsesteeg 1, 6708 PB Wageningen, The Netherlands \\ ${ }^{\mathrm{b}}$ Department of Plant Production and Soil Science, University of Pretoria, Pretoria 0002, South Africa \\ ${ }^{c}$ Potatoes South Africa, Private Bag X135, Pretoria 0001, South Africa \\ ${ }^{\mathrm{d}}$ Ranger Consulting, 3 Laborie Street, Courtrai South Paarl 7646, South Africa
}

\section{A R T I C L E I N F O}

\section{Article history:}

Received 19 July 2010

Received in revised form 3 November 2010

Accepted 5 December 2010

Available online $\mathrm{xxxx}$

\section{Keywords:}

Biocide

Biodiversity

Cape floral kingdom

Fertilizer

Irrigation

Resource use efficiency

\begin{abstract}
A B S T R A C T
The sustainability of agricultural production is linked to the environment from which it draws its resources. Potato production in the Sandveld in the South African Western Cape occurs in the Cape Floral Kingdom: a vulnerable and globally significant biodiversity hotspot. A scientific approach defining and monitoring sustainability criteria and indicators is required to improve the sustainability of potato production in such a sensitive area. In this paper we propose principles related to the ecological impact of potato production (nature preservation, water preservation and the minimization of chemical and carbon-dioxide emissions) and their derived criteria related to land clearing, irrigation, emissions, and others. Next we defined calculable and measurable indicators of the efficiency with which resources are used, such as proportion of land cleared, water use by the crop, amount of biocides used, the embodied energy of biocides, and the energy needed for farming operations versus the potato yields obtained. Indepth interviews were held with 14 farmers representing $20 \%$ of the total potato production area to obtain the current values of these indicators. These were compared to model outcomes of two main sustainability indicators: land and water use efficiency. The land use efficiency varied least between growers, from (36 to $58 \mathrm{Mg}$ (tonnes) ha ${ }^{-1}$ ), water use efficiency returned values between 3 and $9 \mathrm{~g}^{\text {potato } \mathrm{l}^{-1}}$

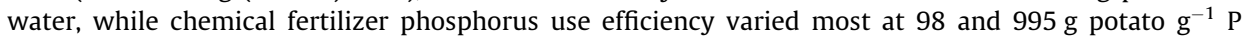
applied. Model outcomes confirmed some of the trends revealed by the survey, e.g. growing potatoes in winter and growing them with less than optimal water offers possibilities to double water use efficiency. Ways to derive indicator threshold norms are proposed based on the knowledge of physical and biological processes determining resource availability, the observed variation among farmers and the model outcomes. Knowing indicator values, their range and the means to improve resource use efficiency will aid in establishing sustainability norms by providing a quantitative approach to any environmental certification scheme that wishes to licence the delivery of potatoes from the Sandveld.
\end{abstract}

() 2010 Elsevier Ltd. All rights reserved.

\section{Introduction}

In South Africa potatoes are grown on approximately 50 thousand hectares and yield close to 2 million tons per annum (Potatoes South Africa, 2010). The most important coastal potato production area in South Africa is the Sandveld located in the Western Cape Province about $200 \mathrm{~km}$ north of Cape Town (Fig. 1). Here, annually framers cultivate about 6600 ha with potatoes under relatively homogeneous production conditions (Potatoes South Africa, 2010). Potato production and processing is the main economic activity in the Sandveld, complemented by some cereal and Rooibos Tea production. Traditionally Sandveld farmers

\footnotetext{
* Corresponding author. Tel.: +31317481376.

E-mail address: Linus.Franke@wur.nl (A.C. Franke).
}

primarily produced seed potatoes. Recently the production of ware potatoes, mainly marketed in Cape Town, Namibia and Angola, has risen in importance.

Farmers grow potatoes year-round and typically obtain average yields of 40-45 tonnes per ha. There is little yield difference between seed and ware potatoes, as seed potatoes are grown for a full season. Any oversized potatoes are sold as ware potatoes. Producers use modern equipment for land preparation, planting and spraying biocides. Pests, especially aphids, and diseases, in particular Phytophthora infestans and Alternaria alternata, necessitate a frequent, often weekly application of crop protection agents. The harvest is frequently semi-manual with potatoes being hand harvested after windrowing. Irrigation constitutes a major investment in potato production. This takes place through centre pivot irrigation systems on fields that range between 12 and 50 ha in size. The water comes almost exclusively from subterranean aquifers, 


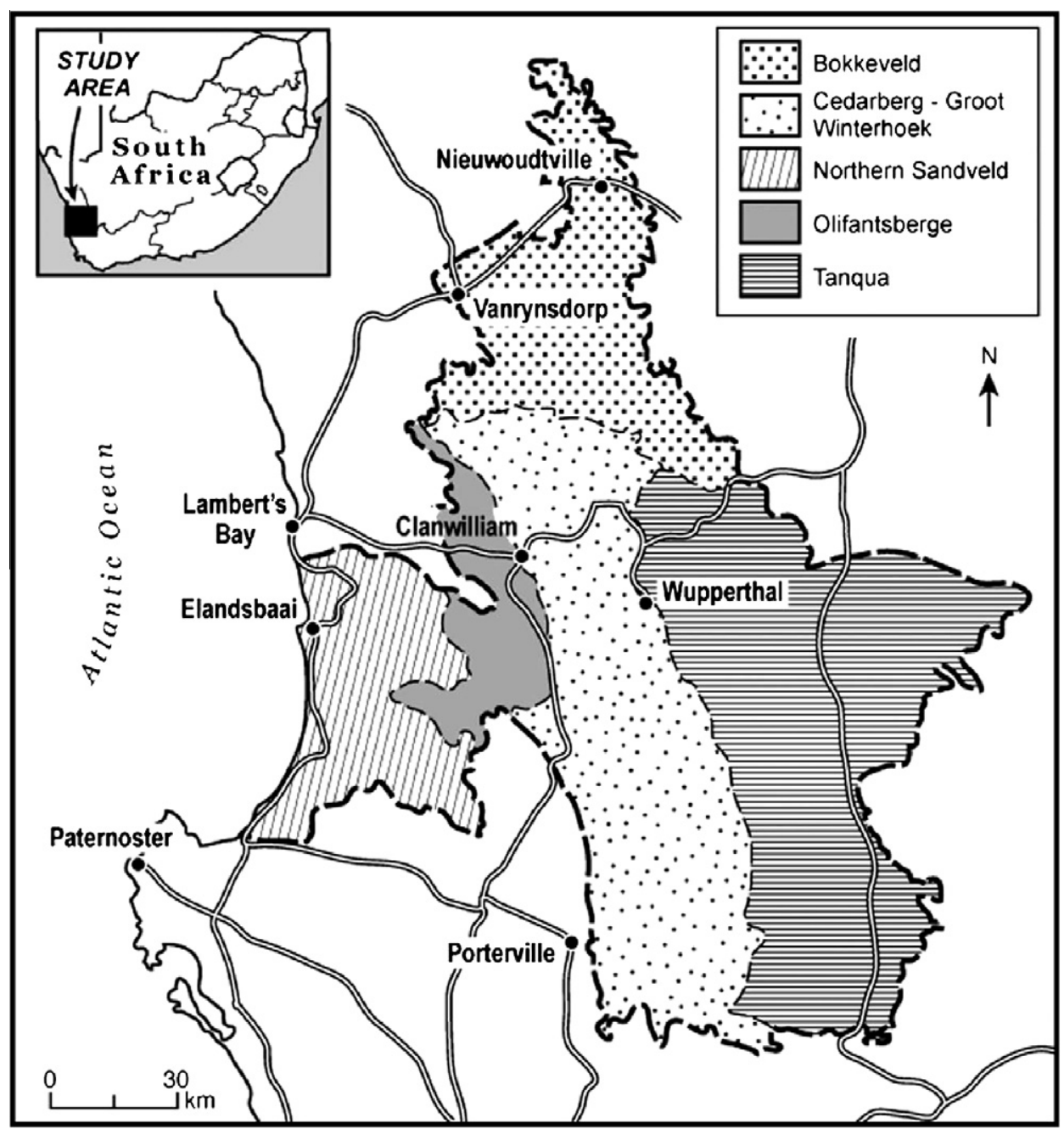

Fig. 1. Map of the Sandveld region in South Africa. Source: Archer et al. (2009).

located between 0.5 and $100 \mathrm{~m}$ below ground level (CapeNature, 2006). The heavy dependency on groundwater has resulted in lowering groundwater levels and a deterioration of water quality through the infiltration of salt into the deep water layers in some areas (Conrad and Munch, 2006). Moreover, over-irrigation could enhance leaching of agro-chemicals to groundwater reserves and, through lowering of groundwater levels, impact on water dependent ecosystems.

The insufficiency of irrigation water in the Sandveld strongly limits the possibilities to profitably grow crops other than potato. The presence of soil-borne diseases, the abundance of land and in some cases phytosanitary requirements for seed potato production, resulted in long fallow periods between potato cultivations. Typically a pivot field is used once in 4-6 years for potato production. The potato crop stays in-field for about 120 days, thus on average one of approximately 15 fields contains a growing potato crop at a given time. This means the total area of Fynbos cleared for potato production is approximately 15 times the actual need if continuous cropping year-round were feasible and soil-borne diseases were negligible. As farmers generally own large holdings (several thousand hectares), only part of the farm is cleared for irrigated production.

The Sandveld is located in the Fynbos biome and more importantly in the Cape Floristic Region which is the smallest of the six recognised floral kingdoms and is regarded as one of the most important of the 34 biodiversity hotspots globally. A biodiversity hotspot is a region that contains at least 1500 species of vascular plants ( $>0.5 \%$ of the world's total) as endemics, and has lost at least $70 \%$ of its original habitat (Myer et al., 2000). Potato production in the Fynbos biome is a major cause for concern as it has resulted in a situation where certain ecosystems directly impacted by this activity are now some of the most threatened in South Africa. Primary impacts are related to the clearing of natural vegetation, the abstraction of water and the release of nutrients and biocides. Farmers also play a pivotal role in protecting Fynbos, as they own most of the land in the Sandveld. Sections of farm properties not used for arable production are valuable as conservation areas for highly threatened ecosystems and localised species. Natural vegetation connected across different properties form continuous corridors across edaphic interfaces, rainfall and altitudinal gradients. These biodiversity corridors are essential to maintain connectivity between species populations and to allow species to migrate across the landscape, especially if ecological zones shift in response to climate change. Former arable lands left to rehabilitate can take up a role as biodiversity corridor, although it often takes at least several decades until the land has regained most of its original vegetation.

These ecological impacts, as well as the economic importance of potato production in the region raised concerns about the sustainability of Sandveld potato production. These were addressed in a collaborative initiative launched in 2007 by Potato South Africa and CapeNature (Knight et al., 2007). This study intends to support 
this initiative by defining sustainability principles, criteria, indicators and norms for potato production in the Sandveld. Four main principles and a set of underlying criteria and indicators for sustainability were developed in this study:

Principle 1 on land: a representative sample of biodiversity for the area should be conserved

Criterion 1: the area of cleared lands required for potato production should be minimized

Indicator 1: potato yield per season per field.

Indicator 2: potato production on all cleared fields of a farm per year.

Criterion 2: the proportion of farm land cleared for potato production should be minimized

Indicator: the proportion of the farm property cleared for potato cultivation.

Principle 2 on water: water reserves in the Fynbos biome should not be threatened by potato production

Criterion: the quantity and quality of the fresh water reserves in the Sandveld should be preserved

Indicator 1: the total amount of water available for a crop from rain and irrigation.

Indicator 2: the amount of water used to irrigate a crop. Indicator 3: the amount of water evapotranspired by the crop and the soil.

Principle 3 on chemicals: the quality and quantity of biodiversity should not be threatened by the use of chemicals

Criterion 1: toxic substances emitted to the environment

adjacent to the potato field should be minimized

Indicator 1: the amount of biocides (insecticides, nematicides, fungicides and herbicides) used.

Indicator 2: the environmental impact of the biocides used.

Criterion 2: fertilizers should not pollute groundwater and application rates should approach crop uptake

Indicator: the amount of nutrients (nitrogen, phosphorus and potassium) applied.

Principle 4 on energy: the contribution of potato production to carbon-dioxide emissions should be minimal

Criterion 1: the energy contained in crop inputs should be minimized

Indicator 1: the amount of energy in biocides.

Indicator 2: the amount of energy in fertilizers.

Criterion 2: the energy needed for crop management operations should be minimized
Indicator: the amount of energy required for irrigation, machinery and transport.

Most of the indicators above can be expressed as resource use efficiencies. For instance, "the amount of biocides used" may be expressed as biocide use efficiency being equal to the mass of potato yielded per $g$ of active ingredient applied. Each of these indicators have values of actual and desired levels of resource use efficiency. Haverkort et al. (2009) described through a crop production ecology approach of sustainable crop production how sustainability indicator values expressed as resource use efficiencies may range from an unacceptably low value to an acceptable level of sustainability (Fig. 2). Where values between levels of acceptability are encountered, crop management must be aimed at shifting the value higher (improving resource use efficiency) within a grace period during which the progress of the grower is monitored.

This paper aims to contribute to the discussion on quantitative assessment of sustainable agricultural production, with potato production in the Sandveld chosen as a case study. We determined the present values of sustainability indicators of potato production in the Sandveld through a field survey and modelling approach. Furthermore we proposed methods that can be followed to determine values for unsustainable and sustainable management practices. We have limited the scope of our investigation to the environmental aspects of potato production in the Sandveld and not the economic nor societal aspects.

\section{Materials and methods}

\subsection{Survey and model}

A farm survey was conducted to quantify the current values of sustainability indicators on potato farms in the Sandveld and the variability in performance between farms. Some of the indicators assessed in the survey (land and water use efficiencies) were benchmarked against the results of an eco-physiological potato growth model parameterized for Sandveld conditions (Spitters, 1990). The water use efficiency indicator based on evapotranspiration by the crop and the soil could only be calculated through the model, as no actual evapotranspiration was measured.

The box of Fig. 3 summarizes the questions asked in the survey, conducted in May-September 2009, involving 14 out of a total of 89 growers in the area. These 14 producers represent about $20 \%$ of the total potato production area in the Sandveld. The farmers were selected to represent a broad cross section of farm and field sizes, water quality, distance from the sea and technology usage levels. Some questions regarding farm field sizes and irrigation

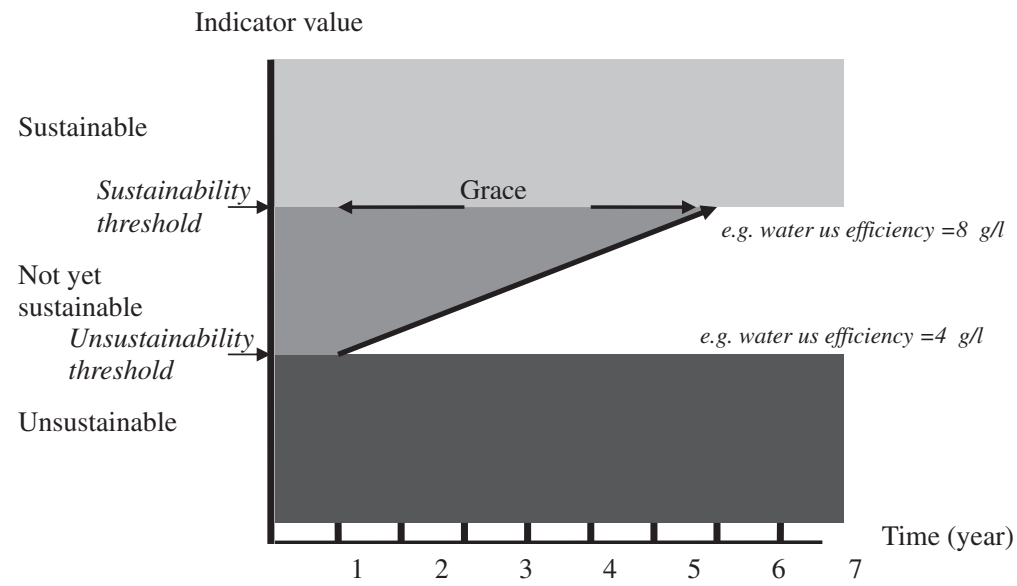

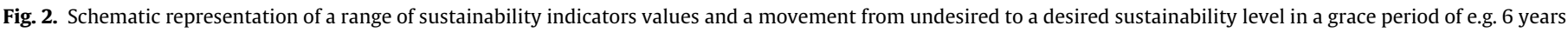
(from Haverkort et al. 2009). 


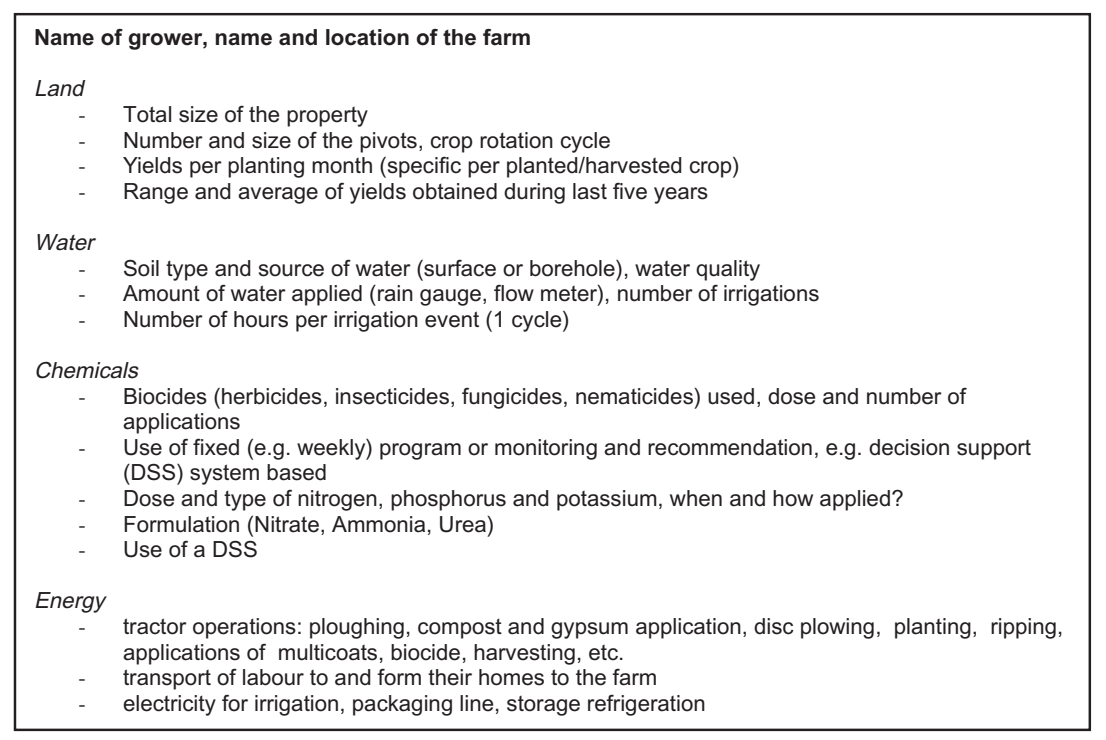

Fig. 3. Summary of the survey completed through interviews with growers.

Table 1

Sustainability indicators, their abbreviations and the quantified magnitude for the current study.

\begin{tabular}{|c|c|c|c|}
\hline Theme & Indicator & Abbreviation & Magnitude \\
\hline Land & $\begin{array}{l}\text { Yield per area of a field per single season in a year } \\
\text { Total yield per all fields on the farm in a year } \\
\text { Proportion of the total farm property cleared for potato production }\end{array}$ & $\begin{array}{l}\text { LUE }_{\text {per field }} \\
\text { LUE }_{\text {all fields }} \\
\text { LUE }_{\text {farm }}\end{array}$ & $\begin{array}{l}\text { Mg potato ha } \\
\text { Mg potato ha } \\
\%\end{array}$ \\
\hline Water & $\begin{array}{l}\text { Water use efficiency based on rain and irrigation } \\
\text { Water use efficiency based on irrigation } \\
\text { Water use efficiency based on evapotranspiration by the crop and the soil }\end{array}$ & $\begin{array}{l}\text { WUE }_{r+i} \\
\text { WUE }_{i} \\
\text { WUEE }_{\mathrm{ET}}\end{array}$ & $\begin{array}{l}\text { g potato } \mathrm{l}^{-1} \text { water } \\
\text { g potato } \mathrm{I}^{-1} \text { water } \\
\text { g potato } \mathrm{I}^{-1} \text { water }\end{array}$ \\
\hline Chemicals & $\begin{array}{l}\text { Biocide (nematicide, fungicide, insecticide, herbicide) use efficiency } \\
\text { EIQ use efficiency } \\
\text { Fertilizer (nitrogen, phosphorus, potassium) use efficiency }\end{array}$ & $\begin{array}{l}\text { BUE } \\
\text { EIQUE } \\
\text { FUE }_{\mathrm{N}} \\
\text { FUE }_{\mathrm{P}} \\
\text { FUE }_{\mathrm{K}}\end{array}$ & $\begin{array}{l}\mathrm{kg} \text { potato } \mathrm{g}^{-1} \text { active ingredient applied } \\
\mathrm{kg} \text { potato per unit of Environmental Impact Quotient } \\
\mathrm{g} \text { potato } \mathrm{g}^{-1} \text { of } \mathrm{N}, \mathrm{P} \text { or } \mathrm{K} \text { applied }\end{array}$ \\
\hline Energy & $\begin{array}{l}\text { Energy use efficiency based on energy embodied in biocides } \\
\text { and fertilizers, and energy used for operations }\end{array}$ & $\begin{array}{l}\text { EUE }_{\text {biocides }} \\
\text { EUE }_{\text {fertilizer }} \\
\text { EUE }_{\text {operations }} \\
\text { EUE }_{\text {all inputs }}\end{array}$ & g potato $\mathrm{MJ}^{-1}$ energy used \\
\hline
\end{tabular}

volumes could be answered easily by interviewees. For other questions (e.g. fertilizer, electricity, labour) bookkeeping records and energy billing accounts were consulted. For others related to the type, dose and frequency of biocide applications, information from chemical advisors and chemical company spray programs was sourced.

The indicators and their dimensions assessed through the survey and the model (Table 1) reflect the principles defined in the introduction of this paper. Since farmers only cultivate part of the total farm and crops are grown in a wide rotation, we distinguished the land use efficiency (LUE) as yield per hectare of a potato field, annual potato yield averaged over all fields of the farm under irrigation and LUE of the entire farm expressed as a proportion of the total property used for arable production. While a high land use efficiency of fields cleared for potato production is desirable, a low LUE of the entire farm is beneficial for the protection of Fynbos vegetation. Water use efficiencies were based on the amount of irrigation water applied $\left(\mathrm{WUE}_{i}\right)$, the amount of irrigation water plus rainfall $\left(\mathrm{WUE}_{i+r}\right)$ and on the amount of water evapotranspired by the crop and the soil as calculated by the model
$\left(\mathrm{WUE}_{\mathrm{ET}}\right)$. The calculation of rainfall received by a potato crop on a given farm, used to assess on-farm WUE, was based on the total annual rainfall on the farm, planting date, growing period and the monthly distribution of rainfall as recorded in long-term weather data from the Sandveld. The environmental impact from biocides was quantified using the Environmental Impact Quotient (EIQ). The EIQ is based on the estimated impact of the active ingredients in the biocide on the ecology of the production area, farm workers and consumers (Kovach et al., 2010). A field EIQ was obtained by multiplying the application rate of each active ingredient with its associated EIQ value. The mass of potatoes produced per unit of field EIQ gave the EIQ use efficiency. To assess energy use efficiencies, input data were converted to their energy equivalent values (e.g. energy content of $1 \mathrm{~kg}$ of nitrate in $\mathrm{MJ} \mathrm{kg}^{-1}$ or $1 \mathrm{~kg}$ of a specific biocide in $\mathrm{MJ} \mathrm{kg}^{-1}$ ) using conversion data as proposed by Green (1987) and Audsley et al. (1997). Of each indicator, the average value per farm was calculated and this value was used for further analyses. Correlations between indicators were analysed with simple linear regression tests using the software package of GenStat 12.1 . 
Table 2

Climate in the Sandveld (Graafwater weather station), average over 1990-2008.

\begin{tabular}{|c|c|c|c|c|c|c|}
\hline Month & $\begin{array}{l}\text { Monthly } \\
\text { rainfall (mm) }\end{array}$ & $\begin{array}{l}\text { Daily minimum } \\
\text { temperature }\left({ }^{\circ} \mathrm{C}\right)\end{array}$ & $\begin{array}{l}\text { Daily maximum } \\
\text { temperature }\left({ }^{\circ} \mathrm{C}\right)\end{array}$ & $\begin{array}{l}\text { No. of days with } \\
\text { average temperature }<12{ }^{\circ} \mathrm{C}\end{array}$ & $\begin{array}{l}\text { No. of days with } \\
\text { maximum temperature }>32{ }^{\circ} \mathrm{C}\end{array}$ & $\begin{array}{l}\text { Radiation } \\
\left(\mathrm{MJ} \mathrm{m}^{-2} \mathrm{~d}^{-1}\right)\end{array}$ \\
\hline January & 6 & 15.0 & 31.3 & 0 & 13 & 27 \\
\hline February & 6 & 15.4 & 31.6 & 0 & 12 & 23 \\
\hline March & 7 & 14.4 & 30.5 & 0 & 11 & 20 \\
\hline April & 25 & 12.7 & 27.3 & 0 & 7 & 14 \\
\hline May & 41 & 10.7 & 23.7 & 2 & 3 & 11 \\
\hline June & 49 & 8.7 & 20.4 & 6 & 0 & 8 \\
\hline July & 56 & 8.1 & 20.0 & 9 & 0 & 9 \\
\hline August & 39 & 7.5 & 20.2 & 9 & 0 & 11 \\
\hline September & 26 & 8.9 & 23.2 & 2 & 3 & 15 \\
\hline October & 18 & 10.8 & 26.0 & 0 & 5 & 19 \\
\hline November & 12 & 12.5 & 27.7 & 0 & 6 & 22 \\
\hline December & 13 & 14.4 & 29.7 & 0 & 9 & 23 \\
\hline
\end{tabular}

The LINTUL crop growth model used in the present study calculates potato dry matter production from the amount of intercepted radiation by its green foliage and a constant conversion factor (light use efficiency) (Spitters, 1990). The current LINTUL model for potatoes followed the approach of Kooman and Haverkort (1994) by calculating the temperature-dependent phenological development of a potato crop. In general, higher temperatures lead to earlier crop emergence and a more rapid initial leaf growth. This results in increased interception of solar radiation at early stages of crop growth, but also a rapid maturation of the crop and a reduced length of the growing cycle from planting to harvest. Moreover, very high temperatures reduce photosynthesis and thereby biomass accumulation. Potato varieties react differently to temperature and day length, so parameters in Kooman and Haverkort's (1994) model were variety-specific.

In our model, shoot growth, foliar expansion, biomass accumulation and tuber growth were simulated on a day-to-day basis. Climate input data included daily minimum and maximum temperatures, incoming radiation and rainfall. Management input data included irrigation regime, and the depth and date of planting. Accumulated degree days from planting (with a base temperature of $2{ }^{\circ} \mathrm{C}$ ) determined the time to crop emergence, leaf area development and the time of crop termination. The leaf area index (LAI) increased exponentially from crop emergence until a leaf area index of 0.75 was achieved. Thereafter, its development depended on temperature and water availability until a full crop cover was reached (LAI > 3). Daily biomass growth was calculated using the crop's LAI, light interception (using an extinction coefficient of 1 (Spitters and Schapendonk, 1990)), and the light use efficiency (1.25 g dry matter $\mathrm{MJ}^{-1}$ of intercepted light). In the model, photosynthesis capacity was reduced when the average day temperature fell below $16^{\circ} \mathrm{C}$ or when the maximum temperature exceeded $30^{\circ} \mathrm{C}$ and was completely halted at temperatures below $2{ }^{\circ} \mathrm{C}$ and above $38^{\circ} \mathrm{C}$ (Kooman and Haverkort, 1994). Besides temperature, drought stress limited photosynthesis and slowed down foliar expansion. Daily potential evapotranspiration (PET) for potatoes was calculated from the Penman-Monteith grass reference evapotranspiration (ETo) (Smith et al., 1996) according to the procedure recommended by Allen et al. (1996). Plant available water in the soil depended on irrigation and rain, as well as the water holding capacity of the soil determining drainage, the rooting zone of the crop (up to $0.5 \mathrm{~m}$ ) and evapotranspiration from the soil and the crop. The actual transpiration by the crop, and thereby the water-limited photosynthesis rate, equalled the potential evapotranspiration by the crop multiplied by a drought stress factor, which was a function of the plant available water in the soil. The harvest index was set at 0.75 ; the tuber dry matter concentration at 20\% (Kooman and Haverkort, 1994).

The model was used to simulate potential and water limited yield of potatoes in the Sandveld. Scenarios were simulated with
18 years of weather data collected between 1990 and 2008 (data from 2000 were omitted due to data gaps) at Graafwater $\left(32.1528^{\circ} \mathrm{S}, 18.6049^{\circ} \mathrm{E}, 205 \mathrm{~m}\right.$ above sea level). Soil data was provided by samples taken from five different farms distributed across the Sandveld region and analysed by the soil science laboratory, University of Pretoria, for soil physical and water holding parameters. The effect of different planting dates on crop performance was assessed by simulating planting on the 15th day of each month between 1990 and 2007. The effect of drought stress on yield was explored by applying irrigation regimes varying between 2 and $10 \mathrm{~mm}$ water per day. Before planting a standard irrigation of $50 \mathrm{~mm}$ water was given, as farmers commonly apply in preparing the soil. In the model crops were not irrigated for 1 day if it rained more than the scheduled amount of irrigation, and for 2 days if it rained more than twice the scheduled amount. The effective irrigation was assumed to equal $80 \%$ of the applied irrigation to account for losses during application. Simulated yields were presented as tuber fresh matter to allow comparisons with actual yields reported by farmers.

Results from the modelling exercise were presented before the outcomes of the survey, where appropriate. The model gave insight in mechanisms, such as the way seasonal weather conditions impact land and water use efficiencies, which subsequently helped to explain the results from the survey.

\subsection{Weather and soil conditions}

The Sandveld has a dry Mediterranean climate with mild winters (June-August), hot summers (November-April) and most rain falling in winter (Table 2). Long-term average annual rainfall in the Sandveld is close to $300 \mathrm{~mm}$. In summer high temperatures often limit the growth of potato, with January, February and March being the hottest months. In winter (June, July and August), photosynthesis is limited by cool temperatures and low radiation intensities. Frost only occurs in the more inland areas and is generally not a threat to potato production.

Soils in the Sandveld consist of coarse sand with a low water holding capacity, a very low organic matter content and low CEC (Table 3 ). Therefore the soils require frequent fertilization with nutrients such as nitrate and potassium, which hardly bind to the soil complex. The low water holding capacity implies that the risk of water drainage and nutrient leaching is high during irrigation.

\section{Results}

\subsection{Land}

The model simulations showed that potential yields in the Sandveld vary between 52 and $96 \mathrm{Mg}$ (tonnes) $\mathrm{ha}^{-1}$ and that the 
Table 3

Soil physical and water holding characteristics of the topsoil $(0-250 \mathrm{~mm})$ and subsoil $(250-500 \mathrm{~mm})$ of a soil typically used for potato production in the Sandveld.

\begin{tabular}{lcc}
\hline Soil property & \multicolumn{2}{l}{ Soil depth $(\mathrm{mm})$} \\
\cline { 2 - 3 } & $0-250$ & $250-500$ \\
\hline Sand $(0.02-2 \mathrm{~mm})(\%)$ & 94.7 & 94.5 \\
Silt $(0.02-0.002 \mathrm{~mm})(\%)$ & 0.4 & 2.1 \\
Clay $(<0.002 \mathrm{~mm})(\%)$ & 2.1 & 1.0 \\
Volumetric field capacity $\left(\mathrm{m}^{3} \mathrm{~m}^{-3} \mathrm{at}-5 \mathrm{kPa}\right)$ & 5.32 & 4.54 \\
Wilting point $\left(\mathrm{m}^{3} \mathrm{~m}^{-3}\right.$ at $\left.-1500 \mathrm{kPa}\right)$ & 1.88 & 1.25 \\
Total plant available water $(\mathrm{mm})$ & 17.2 & 16.5 \\
$\quad$ in the 0-500 mm root zone & & \\
Organic matter content $(\%)$ & 0.25 & 0.22 \\
Cation exchange capacity $\left(\mathrm{cmol}+\mathrm{kg}^{-1}\right)$ & 1.6 & 1.3 \\
\hline
\end{tabular}

month of planting in the Sandveld has a strong impact on potential yields. These are highest when the crop was planted in AugustNovember and lowest with planting in February-June (Fig. 4). In mid summer (December-January planting) high temperatures frequently reduced photosynthesis capacity, while in winter low solar radiation, and sometimes cold temperatures, limited the rate of photosynthesis in the potato crop (Table 2). Planting in spring (August-November) returned the highest potential yield, as it allowed the crop to take advantage of the increasing solar radiation in spring without suffering from frequent high day temperatures, as is the case with crops planted later in the season.

The survey indicated that fresh potato yield among growers (of all potato crops grown in all seasons over the past 5 years) averaged $44.6 \mathrm{Mg} \mathrm{ha}^{-1}$ with a relatively narrow range between 36.0 and $58.3 \mathrm{Mg} \mathrm{ha}^{-1}$ (Table 4, LUE). This range is not explained by some growers growing seed potatoes, as seed potatoes are allowed to grow until maturity and large tubers are sold as fresh table potatoes. Farmers reported lowest yields for March-May plantings (on average $39.2 \mathrm{Mg} \mathrm{ha}^{-1}$ ) and highest yields for plantings in September-November ( $48.5 \mathrm{Mg} \mathrm{ha}^{-1}$ ). The effect of planting date on actual yields followed the trend observed in the simulated potential yields, although differences in actual yields were smaller. The actual yields were used to calculate other use efficiencies of land, water, biocides, nutrients and energy lower in Table 4 .

The total annual potato production for all the potato fields on a farm was $9.4 \mathrm{Mg} \mathrm{ha}^{-1}$ with a range from 7.2 to $14.6 \mathrm{Mg} \mathrm{ha}^{-1}$. Farmers planted potatoes on a plot once in 3-7 years. No relationship between the length of the rotation and yield was found.

The surveyed farmers owned properties between 1230 and 11,000 ha with areas cleared for potato production between 20 ha (just one field) and 1500 ha (Table 4). The average percentage of the total farm land cleared for potato production $\left(\mathrm{LUE}_{\mathrm{farm}}\right)$
Table 4

Farm characteristics and sustainability indicator values derived from the data supplied by the interviewed growers (average and minimum and maximum values observed). For an explanation of abbreviations, see Table 1 .

\begin{tabular}{|c|c|c|}
\hline & Average & Range \\
\hline Total farm size (ha) & 3271 & $1230-11,000$ \\
\hline Area under irrigation (ha) & 352 & $20-1500$ \\
\hline Rotation length (years) & 4.8 & $4.0-7.0$ \\
\hline $\begin{array}{l}\text { Land } \\
\text { LUE }\left(\mathrm{Mg} \mathrm{ha}^{-1}\right) \\
\text { LUE }_{\text {all fields }}\left(\mathrm{Mg} \mathrm{ha}^{-1}\right) \\
\operatorname{LUE}_{\text {farm }}(\%)\end{array}$ & $\begin{array}{l}44.6 \\
9.4 \\
10.7\end{array}$ & $\begin{array}{l}36.0-58.3 \\
7.2-14.6 \\
0.8-21.1\end{array}$ \\
\hline $\begin{array}{l}\text { Water } \\
\text { WUE }_{r+i}\left(\mathrm{~g} \mathrm{l}^{-1}\right) \\
\text { WUE }_{i}\left(\mathrm{~g} \mathrm{l}^{-1}\right)\end{array}$ & $\begin{array}{l}5.3 \\
6.3\end{array}$ & $\begin{array}{l}2.7-9.1 \\
2.9-12.8\end{array}$ \\
\hline 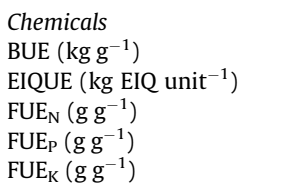 & $\begin{array}{l}2.1 \\
72 \\
166 \\
486 \\
116\end{array}$ & $\begin{array}{l}0.9-4.3 \\
31-180 \\
106-228 \\
98-995 \\
72-164\end{array}$ \\
\hline $\begin{array}{l}\text { Energy } \\
\text { EUE }_{\text {biocides }}\left(\mathrm{g} \mathrm{MJ}^{-1}\right) \\
\text { EUE }_{\text {fertilizer }}\left(\mathrm{g} \mathrm{MJ}^{-1}\right) \\
\text { EUE }_{\text {operations }}\left(\mathrm{g} \mathrm{MJ}^{-1}\right) \\
\text { EUE }_{\text {all inputs }}\left(\mathrm{g} \mathrm{MJ}^{-1}\right)\end{array}$ & $\begin{array}{l}8332 \\
2105 \\
879 \\
541\end{array}$ & $\begin{array}{l}3640-18,368 \\
1471-5181 \\
145-1846 \\
135-1075\end{array}$ \\
\hline
\end{tabular}

was $11 \%$, implying that $89 \%$ was used for other purposes (rooibos tea, grazing land, roads, buildings, etc.). Given the knowledge that about $50 \%$ of the land surface has been changed to agriculture, it is likely there is an additional $39 \%$ of agricultural land already cleared and in many cases lying fallow. In principle expansion of agricultural activities could be limited to the current agricultural land footprint while allowing some of the fallow land is left to rehabilitate. This suggests that Fynbos vegetation could be protected on a substantial part of the farm while maintaining or increasing the current level of potato production. However, potato fields are sometimes located in the most threatened Fynbos vegetation types, e.g. Leipoldtville Sand Fynbos and Graafwater Sandstone Fynbos, and special habitats such as springs, rivers, and wetlands, where species with very limited distributions occur, implying that also current activities threaten Fynbos biodiversity.

\subsection{Water}

Simulated water use efficiencies based on evapotranspiration suggested that a crop growing in winter (planted March-May)

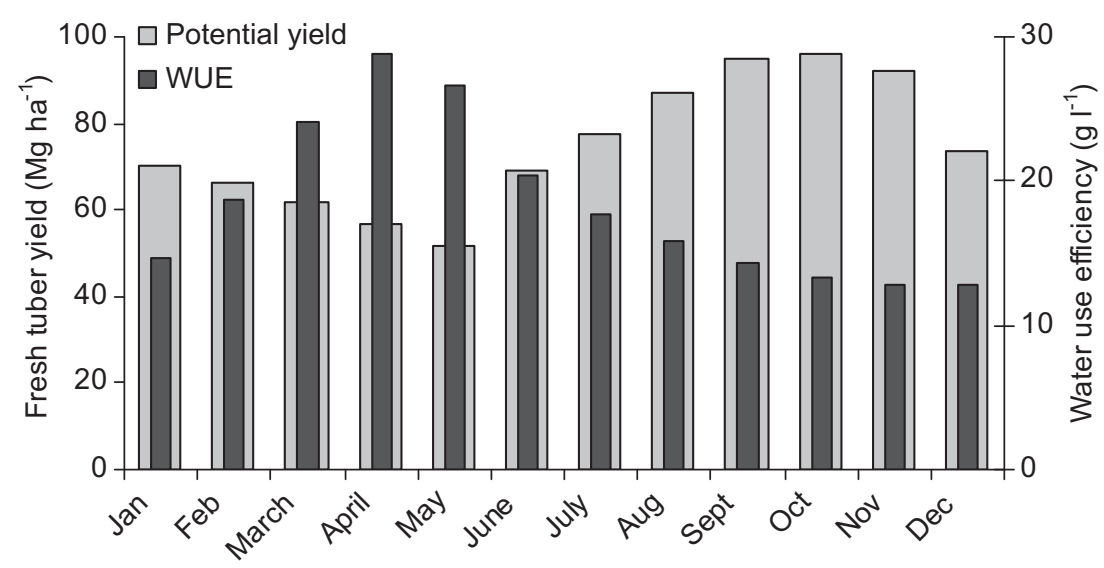

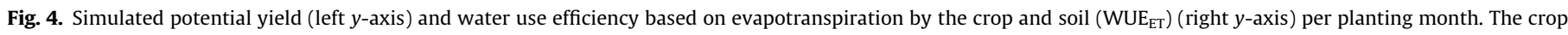
was not stressed for water. 
has a much better WUE $\mathrm{ET}_{\mathrm{ET}}$ than a crop growing in summer (planting October-December) (Fig. 4). High temperatures and radiation intensities in summer resulted in a high evapotranspiration, which was partially compensated for by higher yields. The model clearly indicated the presence of a trade-off between water and land use efficiency, as high potential yields generally coincided with a low WUE $_{\mathrm{ET}}$ and vice versa. Note that these simulations were run assuming the absence of water stress.

Potatoes planted in March-May, when simulated WUE $_{\mathrm{ET}}$ is highest (Fig. 4), also achieved a high simulated WUE based on irrigation and rain, or irrigation only, if the daily irrigation amount was low $\left(2 \mathrm{~mm} \mathrm{~d}^{-1}\right)$ (Table 5 ). The crop barely responded to higher daily irrigation amounts in this period and WUE rapidly declined at higher amounts, suggesting that the risk of over-irrigation and high drainage rates (data not given) is high in this season. A potato crop planted in the period when potential yield is high required more irrigation water, as temperatures were high and rainfall was low in that season, and the crop performed poorly at an irrigation amount of $2 \mathrm{~mm} \mathrm{~d}^{-1}$. An increase in irrigation amount to $4 \mathrm{~mm} \mathrm{~d}^{-1}$ improved yield and water use efficiency, while higher amounts $\left(6-10 \mathrm{~mm} \mathrm{~d}^{-1}\right)$ reduced WUE, but not as much as for a crop growing in winter. The difference between $\mathrm{WUE}_{i+r}$ and $\mathrm{WUE}_{i}$ was higher with planting in March-May, as in winter rainfall contributes to the crop's water supply, while a crop growing in summer depends almost entirely on irrigation water. As winter rains are erratic not all water from precipitation is used effectively as most water from a heavy shower drains away due to the low water retention capacity of the soils.

Surveyed farmers applied on average $5.4 \mathrm{~mm}$ of irrigated water $\mathrm{d}^{-1}$ in a crop planted in March-May and $8.7 \mathrm{~mm}$ in a crop planted in September-November. Such data compare well with those reported by Shahnazari et al. (2007) who found that full additional irrigation during a dry spell yielded $4.8 \mathrm{~g}^{-1} \mathrm{~g}$ and partial irrigation

Table 5

Simulated effect of daily irrigation amount on water use efficiency based on irrigation and rain $\left(\mathrm{WUE}_{i+r}\right)$ and irrigation only $\left(\mathrm{WUE}_{i}\right)$ in the season with a high potential water use efficiency (planting March-May) and the season with a high potential yield (planting September-November) ( $\mathrm{g}$ fresh potato $\mathrm{l}^{-1}$ water).

\begin{tabular}{lrrrrr}
\hline & $2 \mathrm{~mm}$ & $4 \mathrm{~mm}$ & $6 \mathrm{~mm}$ & $8 \mathrm{~mm}$ & $10 \mathrm{~mm}$ \\
\hline WUE $E_{i+r}$ & & & & & \\
March-May & 18.2 & 12.1 & 8.5 & 6.5 & 5.3 \\
September-November & 9.2 & 12.4 & 11.1 & 9.5 & 7.7 \\
WUE & & & & & \\
March-May & 35.0 & 17.0 & 10.7 & 7.7 & 6.1 \\
September-November & 10.8 & 13.5 & 11.7 & 9.9 & 8.0 \\
\hline
\end{tabular}

that was less than crop need yielded $8.3 \mathrm{~g} \mathrm{l}^{-1}$. The variation in daily irrigation amount between farmers was high (between 1.75 and $12.0 \mathrm{~mm} \mathrm{~d}^{-1}$ ) which is reflected in the high variation in WUE achieved by different farmers (Fig. 5 and Table 4). In one instance, for planting in May, a WUE $\mathrm{Wu}_{i}$ as high as $15.4 \mathrm{~g} \mathrm{l}^{-1}$ was recorded. The average efficiency of irrigation for crops planted in March-May was $6.7 \mathrm{~g} \mathrm{l}^{-1}$ whereas it was $4.2 \mathrm{~g} \mathrm{l}^{-1}$ for crops planted in September-November. These results are closely aligned with the outcomes of the model, although WUE levels were higher in the model as stress factors other than water were assumed to be absent. No relationship was found between irrigation rate and yield, or between $\mathrm{WUE}_{i+r}$ or $\mathrm{WUE}_{i}$ and yield for all planting months combined or for particular planting seasons. This and the great range in WUE levels observed highlights the scope that exists to improve WUE without compromising on yield.

\subsection{Chemicals}

For three of the surveyed farms the amount of biocides used could not be established. The BUE on the other farms was on average $2.1 \mathrm{~kg}$ potato $\mathrm{g}^{-1}$ active ingredient with a high variation between farms (Table 4). Fungicides followed by pesticides (including nematicides) made the largest contribution in terms of the volume of biocide used. The range between the highest and lowest efficiencies can be partly explained by the absence of proper decision support systems based on monitoring and a quantitative base. In nearly all instances growers were advised by company representatives who also sold the product onto the producer and sometimes even did the application as a contractor. It can be questioned whether these representatives are interested in keeping biocide use to a necessary minimum. Moreover, growers may oversupply as a kind of insurance assuring the needs are always met. Biocide use efficiency and the environmental impact from biocides, expressed as EIQ use efficiency, were closely correlated $\left(R^{2}=0.669\right)$. However, pesticides resulted in the highest environmental impact, while fungicides contributed most in terms of the total amount of active ingredient used. One farmer had outstandingly high biocide and EIQ use efficiencies compared to the other farmers. This was also the only farmer who did not follow salesmen's advice and who has been schooled in integrated pest and weed control.

Table 4 shows a range of nitrogen use efficiency from 106 to $228 \mathrm{~g}$ potato produced per $\mathrm{g}$ nitrogen applied. This corresponds well with the 229, 188, 166 and $174 \mathrm{~g} \mathrm{~g}^{-1} \mathrm{~N}$ reported by Battilani et al. (2008) as response from various nitrogen application regimes. The range in $\mathrm{P}$ use efficiencies was much larger among farmers than that of $\mathrm{N}$ and $\mathrm{K}$. As the potential for P leaching is low, farmers'

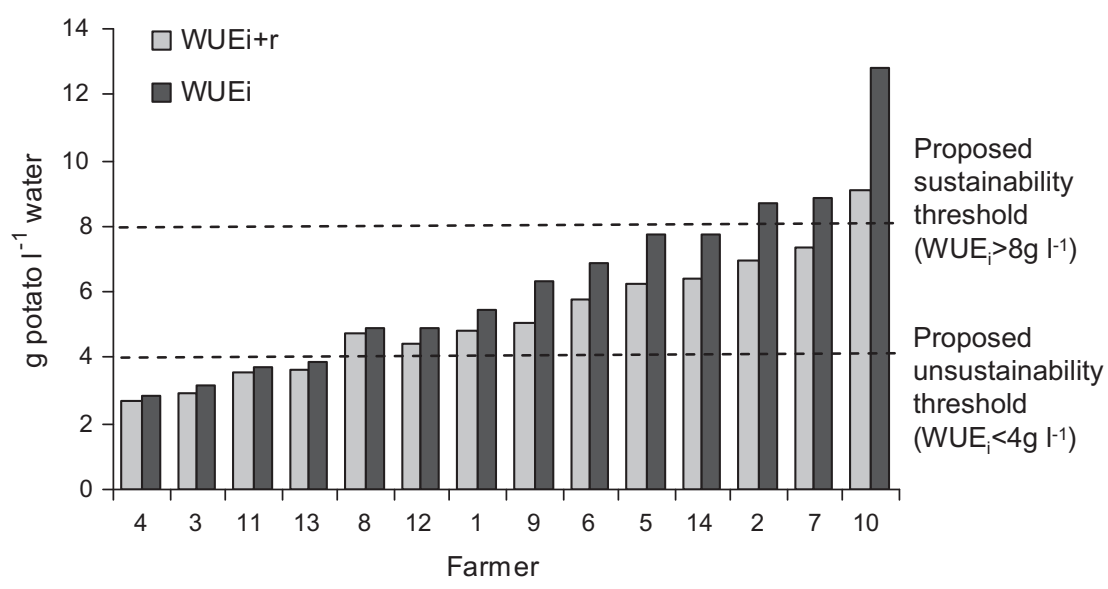

Fig. 5. Range of water use efficiency values based on irrigation and rain $\left(\mathrm{WUE}_{i+r}\right)$ and irrigation only (WUE $\left.{ }_{i}\right)$ observed among farmers. 

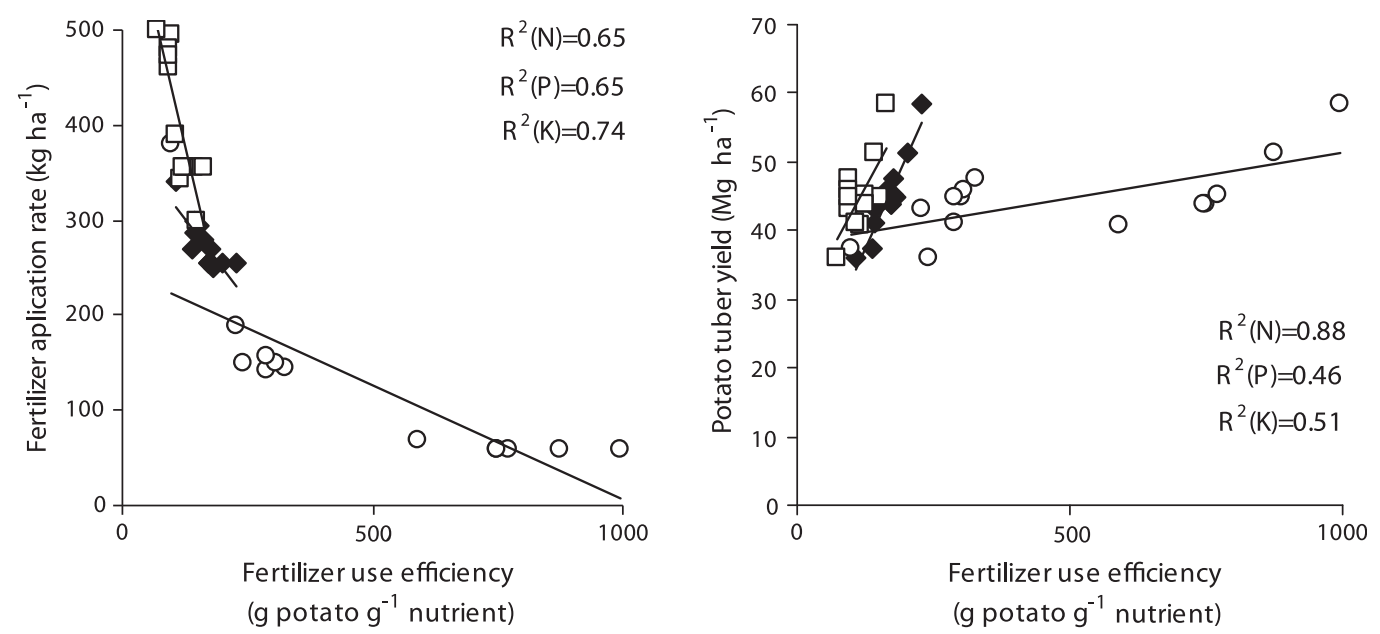

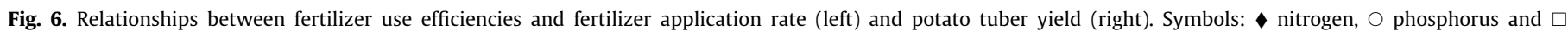
potassium. $R^{2}$ values of correlations are given in the graphs.

application rates may vary a lot from year to year, depending on the soil $\mathrm{P}$ status and available funds. Seemingly high $\mathrm{P}$ use efficiency of $995 \mathrm{~g}$ potato produced $\mathrm{g}^{-1}$ of $\mathrm{P}$ applied approached the equilibrium application of $P$. As expected - the law of the diminishing returns (Mitscherlich, 1909) - there was a negative correlation between the amount of nutrient resource applied and the efficiency with which it contributed to the formation of tuber yield (Fig. 6). The figure also showed a positive correlation between tuber yield and nutrient use efficiency which only seemed logic when considering that growers could improve the nutrient use efficiency of one nutrient by also applying another which was more limiting, following Von Liebig's Law of the Minimum (Browne, 1942). This is supported by the fact that fertilizer use efficiencies of different nutrients were all positively correlated to each other (data not shown), implying that farmers efficient with one nutrient were also efficient with other nutrients (Table 4).

\subsection{Energy}

Most energy was consumed by operations (73\% of total energy use), followed by the production of fertilizers (21\% of total use). The energy required for the production of biocides was relatively minor ( $6 \%$ of total use). The variation in EUE between farmers was large, reflecting the range of inputs used. Additionally, in instances where a farmer grows more in winter and less in summer, the averaged electricity use (pumping of water) on the specific property would be less than the regional average for all farms. The EUE for fertilizers was positively correlated to nitrogen use efficiency, and not to potassium or phosphorus use efficiencies, which is logical considering the fact that the production of nitrogen fertilizer is more energy intensive than that of other fertilizers. EUE was not correlated to yield or irrigation water use efficiency.

\section{Discussion}

A comparison of model outcome and survey results shows that the model systematically calculated higher yields and especially higher water use efficiencies than appeared in the survey. This because the model did not take yield reducing factors such as pests and diseases into account. The model calculations however, were useful as a benchmark, since the trends (e.g. lower water use efficiency in summer and higher water use efficiency when less water is offered than the actual crop requirement) are valid even if the exact data differ from reality. For scientists, policy makers and farmers, the model could be used as a tool to evaluate desired levels of water and land use efficiencies as affected by timing of the cropping season and to allocate priorities to a more efficient use of either the land or water.

Each of the various principles regarding land, biodiversity, water, biocides, nutrients and energy are relevant to the sustainability of potato production. However, it is the conversion of Fynbos vegetation into arable lands that is the main immediate threat to maintaining the diversity of Fynbos in the Sandveld. Changes in groundwater levels and quality are likely to affect water flows and thereby the natural vegetation dependent on habitats close to rivers and other water bodies, while emissions of chemicals primarily threaten Fynbos vegetation close to field boundaries. The main immediate ecological threat to sustained potato production in the Sandveld is lowering groundwater levels and reducing water quality, as precipitation is low and without irrigation barely any arable crop can be produced profitably in the area. Energy use efficiency is mostly relevant to the issue of greenhouse gas emissions and climate change. While climate change is a threat to Fynbos vegetation (changing ecological zones with some species having a very limited geographical range) as well as to potato production (increasing heat stress and evapotranspiration), a higher energy use efficiency in potato production in the Sandveld alone will have little impact on the world's total greenhouse gas emissions.

Having quantified the sustainability indicators, norms need to be set reflecting a threshold below which farming is unacceptably unsustainable and a desired sustainability threshold above which farming is sufficiently sustainable with regard to a particular aspect (Fig. 2). Ideally, these norms are based on an understanding of the physical and biological processes in the (agro)ecosystem determining resource availability. With regard to land use efficiency and the conversion or rehabilitation of Fynbos vegetation, such knowledge is available, providing opportunities to set norms locally and regionally. Sustaining the Fynbos vegetation requires a regional target for each ecosystem as connectivity between ecosystems is essential for natural ecosystems to persist. Additionally, as the spatial distribution of biodiversity is patchy, each farm should have unique thresholds. In this instance fine-scale conservation planning makes it possible to know how many hectares of Fynbos need to be conserved on each property to sustain diversity regionally (Maree and Vromans, 2010). A limit to the proportion of land that can be used for potato production will stimulate farmers to 
increase the resource use efficiency of land that can be used for potato production either by increasing the production within a crop season or by shortening the duration of the fallow period. Due to the abundance of land, such a stimulant was absent in the past.

Defining sustainability thresholds for water use efficiency is another issue. Ideally, norms for water use efficiency are based on knowledge of critical water abstraction rates at which ground water levels begin to decline or salt water intrude the groundwater. The South Africa Department of Water Affairs has conducted a water reserve determination for the aquifers of the Sandveld, setting a maximum volume of available water for a region. Water is then allocated to end users be they farmers or municipalities based on the amount of water needed to service the needs of people and to retain enough water in reserve to keep ecological processes functioning. The next step would be to license water use per farm. Water use in potato production will in future therefore have a fixed ceiling threshold per property so that the authorities or community can sustainably manage the resource regionally through water users associations. Once licensing is in place, water use efficiency will become a measure of a producer's ability to remain economically viable within the sustainability threshold set for the property by the license. The licensing step however is still years away in the Sandveld and for the moment alternative procedures are required to set norms for water use.

Sustainability threshold levels could also be based on the observed variation in resource use efficiency among farmers. The variation in irrigation water use efficiency among surveyed farmers was high, while there was no correlation between irrigation rate and yield. This, as well as some of the high daily irrigation amounts reported by some farmers suggested that farmers with a low water use efficiency over-irrigated their crop, especially in winter. It may be suggested that $20 \%$ of the farmers with the lowest water use efficiency are too inefficient with irrigation water to be considered sustainable and should improve their performance immediately. The $20 \%$ farmers with the highest water use efficiency may be regarded sustainable with regard to this aspect. The middle group in terms of water use efficiency should make efforts to improve their water use efficiency within a certain time period. An example of how this norm setting could work out is given in Fig. 5. As farmers gradually improve their water use efficiency, critical minimum and desired norms for sustainability change simultaneously and sustainability becomes a moving target. Resource use efficiencies obviously cannot increase perpetually and at some point farmers will approach the best attainable resource use efficiency under the given production conditions. By then, if agro-ecological production conditions for farmers are homogenous, as is to a large extent the case in the Sandveld, variation in resource use efficiency among farmers is expected to be small. Also a crop model such as the one applied in this study can help to define potential and attainable water use efficiencies which can be used to set norms for potato production. For instance, farmers that perform worse than $50 \%$ of the theoretical model performance should rapidly improve their performance. In a similar manner as described above thresholds for biocide, fertilizer and energy use efficiency can be set. The survey indicated that the variation between farmers in these resource use efficiencies was also high, while correlations between these efficiencies and yield were absent (biocides and energy) or positive (fertilizers). This suggests that most farmers currently perform well below the attainable resource use efficiencies in this environment.

The approach to set norms based on the relative performance of farmers or benchmarked against model performance is not a guarantee that sustainability with regard to the relevant issue is achieved. For instance, if all potato growers approach maximum attainable water use efficiency, groundwater sources may still be over-exploited and regional sustainability goals may not be reached. Within the Sandveld, the biodiversity associated with particular Fynbos vegetation types and habitats such as springs and rivers is more threatened than biodiversity elsewhere, and fine-scale norm setting could also be appropriate for indicators other than land use efficiency. After the establishment of a sustainability scheme, frequent monitoring of ecological parameters such as water tables, salt intrusion and accumulation of biocides and minerals in soil and ground water is likely to remain a necessity.

This study focused on the ecological impact of potato production and not on economic or societal aspects of sustainability. A framework to assess the economic and societal aspects of sustainability can also be developed by defining sustainability principles, a set of underlying criteria and indicators, followed by the determination of sustainability threshold values. Sustainability principles related to the people aspects of sustainability in the present potato case might deal with issues such as labour conditions, and housing standards and educational opportunities for labourers and their families living on-farm. Defining sustainability indicators and setting norms for these aspects differ from those for ecological aspects, as they do not deal with resources that should be used as efficient as possible. Setting indicators and minimum and desirable norms for labour conditions (e.g. sanitary facilities, clothing, exposure to toxic substances and child labour) are often covered by legal minimum standards and checking such sustainability norms is a matter of verification of compliance with the law. Other people aspects such as schooling and housing supplied may depend more on social and ethical demands and therefore may be subject to debate before a norm is set.

The profit aspects of sustainability usually is a question of supply and demand. How profit is distributed over the supply chain may be established by setting norms following consensus. Such consensus often is arrived at by groups organizing themselves such as labour organizations shifting part of the profit to the workers and farmers' cooperatives shifting part of the profit away from the market towards primary production. Here often also legal aspects play a role (e.g. minimum legal wages).

During the implementation of a sustainability scheme, the question may arise whether farmers should comply with all sustainability norms or whether an exchange between different indicators is acceptable. For instance, can a farm with exceptionally high land use efficiency but a poor water use efficiency considered to be sustainable? Some indicators may be given more weight and meeting the sustainability targets for these indicators may be considered an absolute necessity for a license to deliver, whereas a more flexible approach may be used for other indicators. Legal compliance to environmental laws, as those regarding labour, is the absolute minimum requirement for admission to a sustainability scheme. Decisions on setting sustainability norms are open for debate by policymakers, procurers and certifiers together with growers. Once norms have been set, it is left to the growers and their advisors to improve crop management practices to shift the indicator value to the minimum desired sustainability level and beyond.

In the Sandveld, besides farmers' own interests in working towards more resource use efficient potato production, retailers as well as legislative changes are likely to demand more sustainable production practices in the future. This study offered a quantitative approach needed to establish a certification scheme as a licence to deliver potatoes in the Sandveld and assures a common approach and an equal level playing field for all growers in the area. The value of setting norms before they are being imposed, even if the norms are somewhat arbitrary, is in providing a stimulant to farmers to change towards more sustainable production preparing them for future legislation, market demands and environmental changes. This in essence will become a pro-active adaptive strategy that for instance will mitigate the impact of potentially reduced water volumes being available under new licensing or through climatic changes predicted for the Sandveld (Archer et al., 2009). 


\section{Acknowledgements}

The authors gratefully acknowledge the support of Potato South Africa research coordinator Dr. Ben Pieterse, The Netherlands Ministry of Agriculture Prof. Nico Visser Agricultural Counsellor at the Netherlands Embassy in Pretoria and the Sandveld potato farmers for spending valuable time with us and for their traditional much enjoyed hospitality.

\section{References}

Allen, R.G., Smith, M., Pruitt, W.O., Pereira, L.S., 1996. Modifications to the FAO crop coefficient approach. In: Proc. Int. Conf. Evapotranspiration Irrigation Scheduling. San Antonio, Texas, USA, pp. 124-132.

Archer, E.R.M., Conrad, J., Munch, Z., Opperman, D., Tadross, M.A., Venter, J., 2009. Climate change and commercial agribusiness in the semi-arid northern Sandveld, South Africa. J. Integr. Environ. Sci. 6, 139-155.

Audsley, E., Alber, S., Clift, R., Cowell, S., Crettaz, P., Gaillard, G., Hausheer, J., Jolliett, O., Kleijn, R., Motensen, B., Pearce, D., Roger, E., Teilon, H., Weidema, B., van Zeijts, H., 1997. Harmonisation of environmental life cycle assessment for agriculture. Final Report Concerted Action AIR3-CT94-2028. European Commission DG VI Agriculture, Silsoe, UK.

Battilani, A., Plauborg, F.L., Hansen, S., Dolezal, F., Mazurczyk, W., Bizik, J., Coutinho, J., 2008. Nitrogen uptake and nitrogen use efficiency of fertigated potatoes. Acta Hortic. 792, 61-67.

Browne, C.A., 1942. "Justus von Liebig-Man" and "teacher and Liebig and the Law of the Minimum". In: Moulton, F.R. (Ed.), Liebig and After Liebig: A Century of Progress in Agricultural Chemistry. Am. Assoc. Adv. Sci., The Science Press Printing Co., Lancaster, PA, pp. 71-82.

CapeNature, 2006. Groundwater Assessment of the North-West Sandveld and Saldanha Peninsula as an Integral Component of the Cape Fine-Scale Biodiversity Planning Project. Component 5.1, Fine-scale biodiversity planning. Consultancy Report Submitted by GEOSS to CapeNature, Cape Town.

Conrad, J., Munch, Z., 2006. Groundwater reserve determination required for the Sandveld, Olifants-Doorn water management area. Final report Prepared by GEOSS (Pty) Ltd. for the Department of Water Affairs and Forestry, South Africa.
Green, M.B., 1987. Energy in pesticide manufacture, distribution and use. In: Helsel, Z.R. (Ed.), Energy in Plant Nutrition and Pest Control. Energy in World Agriculture, 2. Elsevier, Amsterdam, pp. 165-177.

Haverkort, A.J., Bindraban, P., Conijn, S., de Ruijter, F.J., 2009. A crop production ecology approach of sustainable biomass production for food, feed and fuel. Outlook Agric. 38, 249-258.

Knight, F.H., Conrad, J., Helme, N., 2007. Biodiversity Best Practice Guidelines for Potato Production in the Sandveld, a Biodiversity \& Business Initiative. A Report Submitted to Potato South Africa and CapeNature. <http://www.capeaction. org.za/uploads/Report_bestpractice-potato_2007.pdf> (accessed 07.10).

Kooman, P.L., Haverkort, A.J., 1994. Modelling development and growth of the potato crop influenced by temperature and daylength: LINTUL-POTATO. In: Haverkort, A.J., MacKerron, D.K.L. (Eds.), Ecology and Modeling of Potato Crops Under Conditions Limiting Growth. Kluwer Academic Publishers, Dordrecht, pp. 41-60.

Kovach, J., Petzoldt, C., Degni, J., Tette, J., 2010. A Method to Measure the Environmental Impact of Pesticides. Integrated Pest Management Program, Cornell University, New York. <http://www.nysipm.cornell.edu/publications/ eiq/> (accessed 11.10).

Maree, K.S., Vromans, D.C., 2010. The Biodiversity Sector Plan for the Saldanha Bay, Bergrivier, Cederberg and Matzikama Municipalities: Supporting Land-use Planning and Decision-making in Critical Biodiversity Areas and Ecological Support Areas. Produced by CapeNature as part of the C.A.P.E. Fine-scale Biodiversity Planning Project, Kirstenbosch.

Mitscherlich, E.A., 1909. The law of the minimum and the law of diminishing soil productivity. Landwirtschaftliche Jahrbuecher 38, 537-552. (in German)

Myer, N., Mittermeier, R.A., Mittermeier, C.G., da Fonseca, G.A.B., Kent, J., 2000 Biodiversity hotspots for conservation priorities. Nature 403, 853-858.

Potatoes South Africa, 2010. Representative of the potato producers. <http:// www.potatoes.co.za/> (accessed 07.10).

Shahnazari, A., Liu, F., Andersen, M.N., Jacobsen, S.-E., Jensen, C.R., 2007. Effects of partial root zone drying on yield, tuber size and water use efficiency in potato under field conditions. Field Crop Res. 100, 117-124.

Smith, M., Allen, R.G., Pereira, L.S., 1996. Revised FAO methodology for crop water requirements. In: Proc. Int. Conf. Evapotranspiration and Irrigation Scheduling, San Antonio, Texas, USA, pp. 133-140.

Spitters, C.J.T., 1990. Crop growth models: their usefulness and limitations. Acta Hortic. 267, 349-368.

Spitters, C.J.T., Schapendonk, A.H.C.M., 1990. Evaluation of breeding strategies for drought tolerance in potato by means of crop growth simulation. Plant Soil 123, 193-203. 